\title{
Carácter, destino y emociones
}

\section{Character, Destiny and Emotions}

\author{
Luciano EsPINOSA RUBio
}

Universidad de Salamanca

\section{Resumen}

Hoy día es necesario comprender el tópico del carácter y el destino desde el punto de vista de las emociones porque podemos integrar mejor que nunca algunas perspectivas filosóficas y neurobiológicas. En este artículo intentamos hacerlo en el contexto de la vida cotidiana y el resultado es deliberadamente ambiguo para la antropología y la ética, alejado de las nociones habituales (sujeto, consciencia, libertad, determinismo...) y abierto, por el contrario, a una discusión multidimensional respecto a los diferentes elementos y circunstancias.

Palabras clave: carácter, destino, emociones, neurobiología, determinación

\begin{abstract}
Nowadays it is necessary to understand the Character and Destiny topic from the point of view of emotions because we can integrate some philosophical and neurobiological perspectives better than ever. In this paper the result is deliberately ambiguous for life and for Anthropology and Ethics, far away from the usual notions (subject, consciousness, free will, determinism...) and opened, on the contrary, to a multiform discussion in relation to different elements and circumstances.
\end{abstract}

Keywords: character, destiny, emotions, neurobiology, determination 


\section{Sentido y propósito}

El tema del carácter y el destino es un tópico recurrente en la historia del pensamiento bajo diferentes enfoques, tiene también un peso notable en la literatura y en la cultura popular, como es sabido, y podría decirse que no está lejos de la genética y la neurobiología actuales. Por otro lado, las emociones se han erigido en objeto de creciente interés en diversos campos del conocimiento y en cierto modo sirven de hilo conductor para engarzar sus diferentes perspectivas -como resume bien la teoría de la inteligencia emocional-, hasta el punto de convertirse en un vehículo privilegiado que desemboca en la reflexión ética y política. Dicho con otras palabras, el carácter puede concebirse como crisol de las emociones, de cuya lúcida comprensión -también en la moralidad- se deriva una parte significativa del llamado destino personal y tal vez del colectivo, ya que hay múltiples procesos subyacentes de institucionalización (simbólicos, educativos, sentimentales...). El presupuesto de todo ello es pensar el êthos en su raíz originaria como forma de vida o modo de ser, esto es, como un continuo de planos o unitas multiplex donde caben registros que iremos desgranando, lo cual responde a unas determinadas concepciones antropológicas que le dan fundamento.

Los significados de carácter y destino son tomados aquí en sentido amplio y un tanto utilitario, aprovechando su carga semántica que apela respectivamente a la naturaleza y a la historia, lo que incluye viejos antagonismos pero también una promesa más reciente de complementariedad. A la hora de hacer una reflexión actualizada del asunto no cabe hablar de un determinismo fisiológico o social, ni tampoco de la psicoanalítica "neurosis de destino" que le hace a uno creerse arrastrado por un designio fatal, de modo análogo ${ }^{1}$ a como las naciones se han echado a menudo en brazos de un supuesto mandato histórico. También sería erróneo pensar en una conciencia transparente, pronta a la deliberación y que culmina en una elección libre sin tacha. En ambos casos hay una racionalización excesiva: por un lado aparece un orden previo ya dado que debe seguirse, por el otro un orden por crear de modo irrestricto, pero en ambas variantes prima una pauta inteligible y dadora de sentido. Al contrario, parece más sensato acercarse a la personalidad sin prejuzgarla, por ejemplo refiriéndose a las emociones en clave psicosomática (es decir, arraigadas en el temperamento y a veces inconscientes), como vía de tránsito obligado para entender una libertad real, encarnada y no abstracta, sometida a múltiples presiones. Hay que asomarse - visto desde otro ángulo- a una subjetividad cotidiana perpleja y en constante forcejeo, barrida por impulsos irreductibles y motivaciones confusas, a la par que interpelada por valores e imperativos (no siempre compatibles) con vocación de universalidad.

\footnotetext{
${ }^{1}$ Haya pesimismo fatalista u optimismo mesiánico, se elude la propia responsabilidad moral y/o política de los actos, justificándolos por superiores motivos egocéntricos/nacionalistas de corte teológico, étnico, etc.
} 
Sin entrar de momento en detalles, baste decir que partimos de una concepción biocultural del ser humano ajena al dualismo ${ }^{2}$, luego hace falta una mirada integradora de esos aspectos y de aquellos saberes. Más aún cuando el propio tema a debatir apunta a la naturaleza humana, pues atañe al conjunto del organismo (concebido como fruto de una larga evolución hominizadora donde hay que prestar especial atención al cerebro), lo mismo que a ciertos resortes psicológicos y sociales básicos, así como a la memoria simbólica no menos importante que la genética. Las emociones participan de todo ello, por lo que deben situarse a medio camino entre lo que Richard Dawkins llama -con expresión ya célebre- los genes y los memes (culturales) $^{3}, \mathrm{o}$, dicho desde otras vertientes, entre la esencia y la existencia, entre la pasión y la acción. De asunto tan multidimensional es oportuno hacer una triple lectura, siquiera en términos esquemáticos: una en relación a ciertos antecedentes conceptuales de la historia del pensamiento que proporcionen un marco de referencia teórico, otra fundada en los hallazgos experimentales de la ciencia contemporánea que abran nuevos campos de indagación, y una tercera que extraiga algunas enseñanzas de lo anterior para alimentar la reflexión ética y antropológica, aunque sin pretensiones de elaborar ninguna síntesis final.

Ya se ve que hay mucho de hibridación y de fronteras difusas, tanto en la cosa misma como en los enfoques mentados ${ }^{4}$, cuando se trata de emociones, a su vez planteadas como puente o nexo privilegiado entre eso que llamamos carácter y destino. De hecho, temperamento, emoción, sentimiento, carácter... forman un continuo que se prolonga en la idea y en la acción, más allá de las distinciones analíticas obligadas, pero que no captan la vida real en movimiento. Comprender este flujo es el problema, máxime cuando el humano es el ser complejo y paradójico por excelencia, contemplativo y activo, emotivo y calculador, cómico y trágico a la vez. Para ilustrarlo con un ejemplo paradigmático, valga el discurso que dio Rafael Sánchez Ferlosio -titulado precisamente Carácter y destino- al recibir el Premio Cervantes 2004: Quijote y Sancho son arquetipos también en esto, descritos como personajes de carácter ligados a lo que son más que a lo que hacen, a la vida contingente en lugar de a la necesidad histórica, al acaecer de la realidad presente más que al curso teleológico de las cosas... Y cuando Quijote quiere construirse un destino heroico como caballero andante, lo emprende como prolongación de su carácter, no al revés, de modo que su peculiar naturaleza de loco generoso se antepone a la historia de sus tragicómicas aventuras ${ }^{5}$. Acaso se podría trasponer esta sutil relación del sentir y el

\footnotetext{
2 Cf. mi trabajo "La naturaleza biocultural del ser humano. El centauro ontológico", en Roca, Juan R. (coord.): Varia biologica. Filosofía, ciencia y tecnología, Colección Contextos 17, Universidad de León, 2007, pp. 129-162.

3 Así lo hace al menos desde su obra El gen egoísta de 1977 (trad. Barcelona, Labor, 1979).

4 Véase -para obtener una documentada panorámica temática y bibliográfica- Ramírez Goicoechea, E.: “Antropología 'compleja' de las emociones”, Isegoría, 25, 2001, pp. 177-200.

5 Hasta ahora no publicado, pero fácil de encontrar en la Red.
} 
actuar al antiguo litigio entre ser y deber, es decir, verlo como un afán por no traicionarse - con independencia de que se gane o se pierda- y hacer valer al individuo frente a las convenciones.

Claro que en la vida -a la hora de llevar a la práctica una ética y una estética de la persona entendida como autoexpresión-no siempre encontramos la nitidez de los personajes literarios ni su encomiable autenticidad, sino más bien el ambivalente papel que juegan las emociones. Y a la luz de esa mezcla abigarrada de elementos (orgánicos, psicológicos, biográficos, culturales...), se adivina que puede resultar un papel incómodo, sobre todo cuando a menudo no las controlamos, no nos gustan o ni siquiera sabemos bien qué y cómo sentimos. Así que las emociones conducen a la pregunta por la resbaladiza identidad de cada uno (el carácter), a su vez escindida entre el ser y el hacer, por si es posible o no cambiarla de manera sustancial (el destino), $\mathrm{y}$, finalmente, si podemos dejar de ser quienes somos/nos hacemos y en todo caso si ello es como queremos... Convéngase de momento -para clarificar términos- en que el temperamento es una predisposición general de la sensibilidad y el carácter es el resultado de su desarrollo biográfico en una u otra dirección; así como en que la emoción es una respuesta inmediata de tipo psicofísico que en alguna medida informa, valora y motiva respecto a lo que ocurre dentro y fuera del sujeto, al igual que el sentimiento es la sedimentación consciente y mediata de aquélla. Sin duda que hay un vínculo con las creencias y los deseos, con sus imperativos, necesidades y propósitos, pero no parece que el complejo múltiple arriba mentado se limite a estos parámetros, sino que más bien incluye otros elementos orgánicos y contextuales. Veamos algunos.

\section{Un paseo por la filosofía}

Se proponen tres rápidas incursiones, una dentro del pensamiento antiguo (en clave cosmológica), otra respecto al moderno (en clave física) y la última contemporánea (en clave biológica), de manera que destaquen algunos rasgos convergentes desde esa pluralidad de enfoques. Y es que los autores elegidos pertenecen a la tradición naturalista que ha puesto el acento en la experiencia ética como algo unitario y anclado en una antropología de lo común, es decir, en la continuidad profunda de cuerpo, mente y naturaleza. También coinciden a grandes rasgos en ofrecer una visión de la libertad muy consciente de sus límites o, si se prefiere, en una suerte de realismo ético análogo al político, donde el carácter y el destino sobrevuelan el discurso con una ambivalencia fecunda en torno a lo querido y lo necesario.

2.1. Los interrogantes planteados al final del apartado anterior están en el corazón de la tragedia griega, como es sabido, si bien con un trasfondo religioso deter- 
minante al que se subordina la moralidad, y que reaparece a lo largo de la historia bajo distintas formas de sometimiento de los humanos ante mandatos superiores. El difícil equilibrio entre la motivación humana (ethos) y la inspiración divina (daimon) que aparece en La Iliada se trastoca de manera dolorosa con la imposición del destino para los personajes trágicos, ejecutado paradójicamente por la propia acción ignorante, soberbia y contumaz de éstos: así, la épica resolutiva de Homero se convierte ahora en el drama de la impotencia. Es cierto que la finitud humana, con su carga de ceguera, incertidumbre y falibilidad, es un mal radical previo a todo, pero la desmesura (hybris) de las pasiones lo lleva a sus peores manifestaciones. En el fondo no hay solución posible a los conflictos ni genuina libertad desde el punto de vista humano, pues el héroe será arrastrado -lo quiera o no-por la misteriosa justicia cósmica (dike), a la que voluntaria o involuntariamente se opone, sin saber que a la vez ayuda a cumplirla ${ }^{6}$. En cuanto a la responsabilidad personal, el Edipo que nos presenta Sófocles no es juzgado por sus intenciones, sino por la capacidad posterior de asumir la culpa que le impone su destino (su deseo profundo), aunque fuera involuntaria; de modo semejante a como Antígona y Creonte deben seguir adelante con sus convicciones y aceptar lo inevitable del sangriento choque entre posiciones bien justificadas pero incompatibles. Lo irremediable, en fin, es parte sustancial de la vida y el valor moral consiste en asumirlo por doloroso que resulte, porque -como indica Esquilo- la sabiduría sólo se adquiere por medio del sufrimiento (cf. Agamenón, 175-180). La primera gran formulación filosófica que recoge tales tensiones también pone el acento en el extravío del querer y en que la ignorancia y la imprudencia no tienen excusa, sin que por ello desaparezca la dimensión trágica de quien es siempre desbordado por la situación.

En efecto, cuando Heráclito afirma que el hombre generalmente desconoce la razón común (logos) y se encierra en su pobre perspectiva personal (22 B 2 DK), lo atribuye a su torpeza y vanidad, a la par que reconoce el sentido insondable y evasivo del orden cósmico (22 B 93 DK). Parece que estamos obligados a ser muy conscientes de los límites humanos, ya que hay un choque insalvable entre el conocimiento de la realidad y el carácter inconmensurable de ésta, de modo que la única vía es recurrir al autoexamen, tanto para dominarse y evitar cualquier exceso, como para atisbar en la propia identidad una conexión con el Todo del que se forma parte. De ahí la famosa expresión fundacional del tema que nos ocupa: "El modo de ser del hombre es su genio divino" (22 B 119 DK), a menudo asociada respectivamente a la conjunción de carácter y destino (daimon), donde convergen las dos tradiciones aludidas más arriba: la capacidad humana para actuar, pero a menudo sin saber y siempre en el seno de aquello que le supera. No cabe entrar en el hipotético tras-

${ }^{6}$ Cf. Fernández Pérez, G.: Heráclito: naturaleza y complejidad, Sevilla y Madrid, Thémata y Plaza y Valdés, 2010, cf. pp. 273-ss. 
fondo astral ni en detalles filológicos e historiográficos ${ }^{7}$, baste sugerir que cada uno muestra una nota del universo y tiene acceso, por tanto, a una fuente de inspiración interna por connaturalidad profunda con él, a condición de que sepa desvelarla para acceder así a lo universal. En otras palabras, hay tendencias y rasgos únicos, propensiones íntimas que pueden conducir a la sabiduría o a la desmesura, según sean gestionados y respeten o no el orden cósmico, con el serio inconveniente, sin embargo, de que éste resulta oscuro y azaroso a nuestros ojos. Luego entre carácter y destino puede haber continuidad o traición a lo que uno está llamado a ser, pero siempre acompaña el esfuerzo y una gran dificultad.

Las obvias resonancias pindáricas y délficas -sé el que eres y conócete a ti mismo- están ligadas, y de su cumplimiento depende que la propia identidad sea una cárcel (la trampa del solipsismo) o una forma de plenitud en el marco del Todo (conexión con el logos). El sujeto no puede escapar a su mismidad y en él hay un aliento divino que le enaltece, pero sus limitaciones a menudo pueden más y le condenan a vivir la miseria de un pequeño destino encerrado en su ego, en lugar de la grandeza que podría lograr abriéndose a la superior justicia (o ajustamiento) de lo real. En la mirada griega no hay sitio, por supuesto, para la concepción moderna del individuo (ética de la subjetividad) y éste es puesto en función de lo que le trasciende (en el plano religioso y político), pero quedan apuntados los dilemas que ha de afrontar: seguir correctamente o no el camino que de lo específico le lleva a lo común, para lo cual debe gobernarse con pulso firme (que no es lo mismo que incurrir en la negación represiva), en vez de quedar encerrado dentro de sí y extraviarse respecto al conjunto. Y ahí es donde juegan un papel primordial las emociones como una característica particular, según estén conducidas por la razón que expresa el logos cósmico o, por el contrario, caigan en el delirio. La cuestión es cómo atinar en la traducción y aplicación de esa lógica universal, nunca del todo comprensible, a las múltiples circunstancias de la vida y a la pluralidad de los temperamentos y deseos... Huelga decir que el tema es una constante de la historia cultural de Occidente, pero con muchos y distintos matices de interés.

Sentado este precedente, que podría considerarse canónico, es oportuno resumir algunos de los conceptos que a partir de ahí entran en juego ${ }^{8}$. Para el pensamiento clásico, el ethos se entiende como carácter (kharakter) que origina los actos y a la vez es fruto de los mismos, en la medida en que se configura en forma de hábitos que retroalimentan ese circuito entre lo fundante y lo fundado. Por otra parte, es útil recurrir a la polisemia de la palabra hexis para nombrar lo que a uno le pertenece, pues incluye la constitución orgánica, el talante, la sensibilidad ante el mundo o

\footnotetext{
7 Remito, por ejemplo, a Magris, C.: "Il carattere, per un uomo, é il suo dèmone", en Rossetti, L. (ed.): Atti del Symposium Heracliteum, 1981, vol. I: Studi, Roma, Edizioni dell'Ateneo, 1984, pp. 181-191. 8 Tomo como guía a López Aranguren, J. L.: Ética, Madrid, Alianza Universidad, 1981 (7ª ed.), pp. $22-24$.
} 
temperamento (temperamentum), es decir, lo que se refiere a la naturaleza dada y al modo de ser luego adquirido, por cuanto hay un nexo que es el comportamiento, más tarde denominado habitus (y que los escolásticos llamarán habitudo). Éste es el hilo práctico que atraviesa las distintas cuentas del collar y las une consolidándolas, esto es, la conducta expresa lo dado por naturaleza e incorpora lo aprendido, con evidente repercusión moral. Luego la praxis está constituida por el continuo que va del cuerpo al sentimiento (pathos), de éste a la costumbre y de ahí al carácter como decantación de rasgos personales a lo largo del tiempo (todo lo cual también cae bajo la acepción plena del vocablo latino mos). El problema es que este sentido integrador de la personalidad se va fragmentando y pronto aparece la consideración separada, e incluso opuesta y heterónoma, de cuerpo y alma, vicios, virtudes, deberes, razón y afectos... Cuando el cristianismo lo refiere todo al Dios personal trascendente y a la verdad revelada, además de romperse la comunidad inmanente del logos, aumenta la dificultad para mantener esa unidad originaria de lo ético que comprendía distintos ámbitos o registros existenciales y no requería la gracia.

2.2. En esta cata histórica es obligado dar grandes saltos, y el caso de Spinoza supone un notable giro (ya apuntado en el Renacimiento) al proponer una ontología ajena a los dualismos, lo que propicia una mirada de nuevo integradora respecto al individuo: lo corpóreo y lo mental son dos dimensiones de lo mismo y están en pie de igualdad, tanto a nivel macro como microcósmico (Ética, II, 1 y 2; E, III, 3). Como se recordará, todos los seres particulares son un modo de la sustancia divina -lo absoluto- y participan en un grado determinado de su potencia infinita, de manera que esa cantidad de potencia particular constituye su esencia o conatus (E, III, 4 y ss.). La esencia humana en concreto se llama deseo y es una suerte de energía (de existir y de pensar) que se corresponde en cada sujeto con una singular complexión orgánica (cuya clave física es la proporción de movimiento y reposo de sus partes integrantes), lo que establece un enfoque psicofísico unitario. Además, el sujeto es autoconsciente en virtud de su interacción con el entorno (E, II, 13), pues el contacto entre individuo y mundo genera afecciones (se llama afectos a las ideas de éstas) ${ }^{9}$, cuya múltiple dinámica se clasifica según el tipo de la acción y el de la pasión: la primera incluye los afectos que suponen un aumento de la potencia, dado que el sujeto es causa adecuada de las afecciones que tiene, lo que significa que las entiende aun si no las produce; mientras que la segunda implica un descenso de esa fuerza fundamental por ignorancia, es decir, porque tiene ideas confusas de cuanto ocurre (E, III, Def. 1, 2 y 3). Luego el esclarecimiento o no de lo que uno vive (síntesis de lo interno y lo externo) desemboca en emociones positivas y negativas, respectivamente, a tenor de que uno sea lúcido y por ende dueño de sí mismo, o sea arrastrado por los humores suscitados al albur de las circunstancias.

\footnotetext{
9 Aunque no hay distinción clara, podría decirse que se da la misma relación que entre emoción y sentimiento, en cuanto que el afecto es la toma de conciencia y la percepción duradera de la afección.
} 
Lo interesante es la continuidad y estricta correlación entre afectos y razón, pues ambos planos son expresiones de la misma potencia: entender y así generar afectos dichosos es el principal servicio que la razón presta mediante la idea adecuada de algo (nacida de las nociones comunes que, con reminiscencia heracliteana y estoica, son las que permiten captar las conexiones de lo real), de modo que el sentimiento derivado tiene una carga energética favorable para el individuo una vez que sabe a qué atenerse respecto a sí mismo y a las cosas (E, II, 40, 41, 42). Las ideas no son neutras, sino que conllevan un aumento o decrecimiento del deseo (tienen un tono también afectivo) y eso hace que se retroalimenten las instancias emocionales e intelectuales entre sí de forma beneficiosa o perjudicial. He aquí la raíz inmanente de la ética, concebida como un juego de fuerzas donde la virtud es igual a la potencia (la naturaleza-realidad de un ser), y donde un afecto sólo es desplazado por otro más intenso, al margen de la verdad o falsedad en abstracto de la idea (E, II, 35 escolio y IV, 1 esc.); por lo que, en definitiva, es bueno lo que aumenta la potencia o perfección del ser y malo lo contrario (E, IV, Pref. y Def. 1 y 2). Además, la acción supone afectos relativos a la alegría y la pasión los propios de la tristeza; así que la alegría es buena, más aún si nace de la lucidez y no es sólo casual, y la tristeza es (casi) siempre mala porque reduce las capacidades del sujeto (E, III, Def. Af. 2 y 3). Tales afectos básicos, luego particularizados (p. ej. en fortaleza y generosidad, o en esperanza y miedo, respect.) tienen sentido acumulativo y por eso tiñen la vida en su conjunto de un tono expansivo o reactivo, de manera que el carácter que uno va fraguando constituye un destino que está más cerca del sabio sereno y jovial o del necio triste y variable.

Ahora bien, este aspecto en parte constructivista de la identidad no niega, por un lado, que cada cual tenga su ingenio ${ }^{10}$ o subjetividad característica ni, por otro, que esté sometido a la necesaria concatenación de causas y efectos en la naturaleza que nadie puede abarcar o controlar (E, I, Apéndice). Siempre hay un resto irreductible a lo racional y lo común, tanto por la forma de ser individual como por las muchas cosas que nos arrastran y no podemos conocer, luego en alguna medida retornamos a los límites de los que ya advirtiera Heráclito: no hay plena transparencia entre el mundo y la conciencia, hasta el punto de que suele primar lo compulsivo sobre lo lógico, de ahí que Spinoza guste recordar que somos llevados por afectos contrarios entre sí y que -como dijera Ovidio- aun reconociendo lo mejor con frecuencia seguimos lo peor (E, II, 2 esc.). A veces ni siquiera el conocimiento basta, pues las muchas emociones trenzadas en el ingenio bien pueden escapar a la

\footnotetext{
10 Se retoma el término latino ingenium que incluye disposiciones naturales (natura), temperamento (indole) y forma de ser (mos), asunto ya actualizado entonces por Huarte de San Juan en su célebre Examen de ingenios. En Spinoza aquel vocablo suele referirse a la vida pasional ligada a la imaginación, a los signos externos, las tradiciones, etc., hasta abarcar la idiosincrasia personal y colectiva en sus diferentes planos.
} 
elucidación consciente ${ }^{11}$. Sin embargo, no por ello son enemigas de la razón en general, dado que expresan dos formas de la misma energía del ser y ahí estriba la capacidad de establecer un diálogo ético entre ambos polos: la emoción puede ser una fuerza dichosa que propulsa a la razón y ésta por su parte genera emociones constructivas (E, V, 10 esc.), de modo que la comunidad ontológica posibilita los trasvases. El planteamiento es más flexible que el choque frontal del que hablan los estoicos en clave racionalista o Hume desde el emotivismo, por poner dos ejemplos notables, opuestos entre sí pero ambos unilaterales. En cambio, aquí el sentimiento da que pensar y el pensamiento da que sentir, en un camino de ida y vuelta que llena de contenido a la empresa existencial. Spinoza, en resumen, se basa en la continuidad física de los planos: la idea que es el afecto expresa a la vez la "constitución" del cuerpo, el paso a una mayor o menor potencia y el sentimiento correspondiente (E, III, Def. Gen. Af.), por lo que se recupera la antigua unidad de la experiencia orgánica, emocional e intelectual, también en sentido ético.

2.3. El último jalón de este camino se refiere a la pauta biológica que gobierna el discurso contemporáneo de Schopenhauer y Nietzsche, ambos unidos en la reivindicación de la psicofisiología como aspecto primordial de la vida. Es sabido que el primero inspiró al segundo en su juventud y que éste se alejó después del pesimismo de aquél, pero comparten el empeño por anclar en tierra firme el discurso moral, lo que significa impregnarlo con los humores de una voluntad hecha carne. Por eso los dos autores niegan -como el judío holandés- que haya una libertad incondicionada e insisten en la conducta como fruto de la trabazón de cuerpo y mundo. Veamos algunos apuntes al respecto.

Schopenhauer presenta un carácter innato e inmutable que siempre opera de forma regular y necesaria, una vez estimulado por los motivos circunstanciales que le hacen pasar a la acción, con independencia de que el sujeto sea consciente o no de ello, parezca elegir, etc. ${ }^{12}$. Esta causalidad casi mecánica responde al hecho -como es sabido- de que la voluntad o esencia de las personas es una manifestación de la Voluntad o realidad toda que se afirma en cada una de ellas. Lo notable del caso es que por primera vez el absoluto tiene los rasgos del mal y de la ceguera (al menos en primera instancia), por lo que el deber moral estriba en negar esa volun-

${ }^{11}$ Recuérdese que Spinoza ha sido considerado precursor de la teoría psicoanalítica y cabe destacar su denuncia del mecanismo por el cual la conciencia ordinaria proyecta sus deseos y necesidades a la realidad, dando lugar el prejuicio máximo del finalismo, así como la tendencia general a la superstición producida por el miedo (E, I, Ap. y Tratado teológico-político, Prefacio). He desarrollado todos estos temas desde una perspectiva integradora en Spinoza: naturaleza y ecosistema, Pub. Universidad Pontificia de Salamanca, 1995.

$12 \mathrm{Cf}$. El mundo como voluntad y representación (en adelante MVR), IV, 55, pp. 188-ss. y 203; y Complementos a MVR (en adelante Comp.), II, 25, p.869. (Traducción de Eduardo Ovejero, Madrid, Aguilar, 1927). 
tad en uno mismo y evitar así el sufrimiento derivado de un deseo insaciable. El problema es que el apetito sexual (epítome de la voluntad) y toda clase de pasiones, instintos y emociones se imponen al débil entendimiento (ubicado en el cerebro como polo opuesto a los genitales), de manera que sobreviene el fracaso y la mayoría lleva una vida casi animal. No debería Schopenhauer, sin embargo, criticar esa flaqueza tan acerbamente cuando él mismo asegura que la inteligencia depende de la "vida somática del organismo" y ésta descansa en la voluntad (Comp. IV, 47, p. 1054), de forma que los lazos causales entre esas instancias conducen inevitablemente al desastre. El carácter se conoce a posteriori, a medida que va desenvolviéndose a lo largo del tiempo, y eso proporciona alguna herramienta para precaverse y ejercer alguna prudencia, pero nunca se podrá dejar de ser quien uno es ni poner a la voluntad en contra de sí misma (MVR, IV, pp. 209 y 211, respect.). Luego es imposible lograr un cambio cualitativo cuando la naturaleza de cada uno ya ha trazado el camino, lo que tal vez guarde relación con el predestinacionismo de cuño protestante.

Podrían hacerse bastantes objeciones a la coherencia del discurso y añadir que por detrás del pesimismo hay un sorprendente trasfondo religioso que asegura la salvación personal por la gracia y por la transformación última de la entera realidad $^{13}$, pero ahora importan más las consecuencias prácticas para nuestro tema. En efecto, la voluntad se plasma en el carácter, junto a una determinada disposición orgánica y emocional, de modo que, más que suprimir aquélla (cosa imposible), lo que hay que hacer es contenerla mediante el conocimiento para evitar sus efectos más perniciosos. Proceso de aprendizaje reforzado por una vida ascética y tan consciente como sea posible de la verdad última de uno mismo, a lo que se añadirá la ayuda intersubjetiva nacida de la compasión que funda la moral en casi todas partes. Hay que apreciar en el autor alemán el reconocimiento de la infraestructura preconsciente de la personalidad, por así decir, y el peso de unos patrones internos que nunca desaparecen, aunque se moderen con la experiencia y un relativo autodominio. Así, el exceso fatalista inherente a la voluntad (el carácter es destino sin más) se acompaña de un aviso útil contra los que asumen demasiada plasticidad en la forma de ser o las prerrogativas no menos dudosas del intelectualismo moral. Schopenhauer indica, en fin, que para bien y para mal todos tenemos una impronta anímica insoslayable, el salvaje querer que nos constituye, cuya influencia sólo podemos suavizar.

Por otro lado, la voluntad de poder nietzscheana comparte algunas de las notas recién comentadas, pero aporta novedades relevantes porque no hay un absoluto

13 He intentado probarlo con abundantes textos en "Naturaleza y salvación en Schopenhauer", en García Castillo, P. (ed.): Trabajos y días salmantinos, Salamanca, Anthema Ediciones, 1998, pp. 91102; y en "Necesidad natural y libertad moral en Schopenhauer", Cuadernos Salmantinos de Filosofia XXVI (1999) 171-184. 
metafísico que imponga directrices, una vez que la llamada muerte de Dios derrumba cualquier unidad cósmica, sentido, certeza o finalidad inalterables. Por de pronto, Nietzsche amplía el marco general de referencia para situarse a caballo de la fisiología y la evolución de los organismos, por un lado, y la genealogía histórica de los conceptos, por otro (cf. Humano, demasiado humano, I, 10), lo que da lugar a dos planos diferentes y complementarios que se equilibran, unidos por un sesgo empírico en vez de sólo especulativo. Esa voluntad de poder es diferente en cada uno y se vuelca hacia la autosatisfacción y el dominio dictado por intereses egoístas, esto es, por las necesidades orgánicas y de fortalecimiento del individuo; pero no es perversa y ciega por definición, sino que está dotada de la capacidad de interpretar el tono activo o reactivo de las fuerzas en juego (Genealogía de la moral, II, 12) y de valorar su naturaleza afirmativa o negativa (Más allá del bien y del mal, 19). Luego uno puede orientarse en el camino y no está fijado casi todo de antemano. Lo que importa no es la verdad objetiva y mucho menos el deber entendido como sacrificio, sino que los actos respondan a las exigencias vitales del individuo, a cuyo servicio están el ficcionalismo gnoseológico (las mentiras útiles) y la creación estética que justifica la existencia. Por otro lado, cuando Nietzsche arremete contra el idealismo moral, no sólo siente rabia ante lo que considera hipocresía, sino que le parece algo vacuo e inane porque olvida los procesos orgánicos instintivos y de autorregulación (Más allá..., 36); es decir, porque ignora el sabio poder inconsciente del cuerpo que se proyecta en la conquista del entorno (Genealogía..., I, 2). Lo que se critica, en definitiva, es el hecho de relegar aquello que precisamente da consistencia al sujeto: si triunfa la falsa virtud es a costa de la felicidad y si fracasa desemboca en el remordimiento.

La mentira y el error denunciados estriban en avergonzarse de sí mismos e instaurar valores esclavizantes a la par que inalcanzables, antepuestos a las auténticas necesidades humanas. Por eso dice que se han moralizado-que es lo mismo que "falseado"- asuntos que en rigor son psicofisiológicos, naturales, mientras que el único imperativo válido es reconocerse y aceptarse con coraje, pues en caso contrario es imposible amar a nadie (Ecce homo, "Por qué escribo tan buenos libros", 5). Frente a aquella irrealidad promovida por filósofos y sacerdotes, que finalmente desemboca en el nihilismo pasivo (porque la propia voluntad de verdad produce desengaños sucesivos), es imprescindible una vez más reconocer lo que uno es, en vez de reprimirlo y/o sublimarlo. La tarea no es fácil, como reitera el autor, pero negar la vida sólo acarrea sufrimiento innecesario, y de éste ya hay bastante por sí solo. A la postre, son la sensibilidad animal y la intuición estética las que deben dirigir la nueva empresa hedonista, decantadas en el temperamento ${ }^{14}$ de cada cual, de

14 Es revelador que, poco después y desde otra perspectiva, William James subraye la importancia del temperamento de cada pensador para calibrar su cosmovisión y entender mejor su filosofía, pues aquél es "la más poderosa de todas nuestra premisas", aunque se oculte tras la impersonalidad de los argu- 
donde surge el valor que vence y trasmuta el dolor en sobriedad, alegría y libertad (Humano..., I, 34). Puede pensarse también que hay un impulso innato hacia el fortalecimiento en todo ser no desnaturalizado, y también que los rasgos personales ya están dados en el temple de ánimo que impulsa el carácter en una dirección y aboceta así un destino expansivo o reactivo, lo que permite entender mejor la célebre idea de que no se tiene sino que se es un destino.

Es preciso recalcar que en los cuatro autores mencionados hay una reivindicación de las bases orgánicas del sujeto que, a su vez, fundan los demás aspectos de la existencia, incluidas sus disposiciones y tendencias anímicas y morales. La única forma de construir bien la identidad es tomar conciencia de los condicionantes previos y de las posibilidades inherentes, sin olvidar que son los cauces que permiten un desarrollo real (no ilusorio) de la persona, a la par que limitan su trayectoria. Ahí está implícito, claro está, el problema de la libertad y todos ellos han sido considerados deterministas en diferente medida, sin embargo el asunto no admite las respuestas simples que giran en torno a una oposición abstracta entre lo libre y lo necesario. Quizá sería útil pasar desde la perspectiva macrológica (concatenación causal) del todo hacia la microfísica de las partes (dotadas de intenciones y motivos), esto es, ver a los humanos desde el interior, como algo vivo y complejo, donde lo que rige no es un determinismo genérico, sino una determinación en varios sentidos: a) psicofisiológico, en cuanto que la mente surge de las capacidades del cuerpo y no al revés, pero hay continuidad y retroacción entre ambos planos; b) práctico, en cuanto que la acción arraiga en la tremenda densidad de las vivencias de todo tipo (inconscientes y vegetativas, emocionales e intelectuales, etc.) y no obedece a la sola voluntad, sino a multitud de factores; y c) ontológica, en cuanto que todo sujeto está conformado por relaciones e inmerso en una circunstancia concreta, puesto en situación y atravesado por el mundo, con el que intenta negociar. Cada autor requeriría, desde luego, sus matizaciones (p. ej., los dos primeros se mantienen en la búsqueda de la verdad y los últimos la sustituyen por el arte), pero puede buscarse otro mínimo común denominador en que hablan de necesidad en un sentido neutro, no moralizante: es entendida antes que nada como la afirmación misma del ser (del general y del particular de cada uno), no como su negación, y la libertad realista que proponen se basa en la lucidez previa respecto a ese espesor del yo unido al entorno que nos limita. Se trata de hacer valer hasta donde sea posible la propia naturaleza en el seno de la naturaleza común y no hay una mera conciencia pasiva del orden cósmico, sino que cada cual es una fuerza activa capaz de actuar por sí mismo según razones propias (que aúnan impulso y lucidez) debido justamente a que es parte de lo real, es decir, al hecho de participar de la afirmación/necesidad del Logos, la Potencia, la Voluntad y la Materia del mundo,

mentos, cf. Pragmatismo, Madrid, Alianza, 2000, pp. 57-ss. Sin incurrir en el psicologismo, James demanda examinar las pasiones y las creencias personales para mejor servir a la búsqueda de la verdad. 
respectivamente. Lo que no hay es libertad como indiferencia, sino el arduo cruce de causas externas, decisiones internas, inconsciencia, conocimiento, pasiones, deseos, etc.

\section{Un paseo por la ciencia}

Como se ve, carácter y destino son nociones multívocas, con una larga historia y diferentes acepciones que alimentan su riqueza semántica, pero conviene observarlas también a la luz de la neurobiología y la psicosociología contemporáneas, en aras de la misma pretensión integradora de aspectos y sin abandonar la mirada naturalista. Aún a riesgo de que haya un salto de planos, es necesario contrastar diferentes enfoques y articularlos en alguna medida para tener una mirada poliscópica mínimamente fundada y también empírica.

3.1. El primer dato inequívoco es que el ser humano es fruto de una evolución prolongada y contingente, como es bien sabido, en el que las cosas podían haber sido harto distintas, pero lo cierto es que el proceso hominizador de millones de años ha configurado una determinada estructura genética y orgánica, con una especial relevancia de la cerebralización. Este asunto es recogido en la famosa teoría de Paul Maclean, según la cual el cerebro primate consta de tres niveles o dimensiones que responden a las principales etapas de su génesis, cada uno con pautas propias: el cerebro reptiliano más primitivo (común además a peces, anfibios y aves), dotado de los instintos e impulsos básicos; el nivel medio del cerebro mamífero, sede de las emociones primordiales (miedo, agresividad, cariño...); y el más reciente o cortical, propio de los homínidos, capaz de realizar una coordinación intelectual de la conducta15. Debe subrayarse el efecto acumulativo, donde cada estrato conserva sus rasgos y proporciona claves de comportamiento adquiridas en diferentes períodos y seleccionadas porque contribuyen a la supervivencia. La historia animal de los humanos aparece así con crudeza y hay que asumir que los tres planos están siempre presentes e interactúan en nuestras vidas.

Por otro lado, es fácil advertir que todo ello se corresponde groso modo con las tres grandes partes anatómicas y funcionales del cerebro que vale la pena recordar: a) la vegetativa, constituida por el rombencéfalo (bulbo raquídeo con cerebelo y puente) y el mesencéfalo, que forman el tronco cerebral que rige la respiración, el ritmo cardíaco, el movimiento, la digestión...; b) la emocional, asentada en el diencéfalo o cerebro intermedio y que incorpora el tálamo y el sistema límbico entero (hipotálamo, glándula pituitaria, hipocampos y amígdalas), encargados del control

15 Cf. MacLean, P.: The Triune Brain in Evolution: Role in Paleocerebral Functions, New York, Plenum Press, 1989. 
endocrino, la homeostasis, la sexualidad, la reproducción y las respuestas emocionales básicas; y c) la mental, radicada en el telencéfalo y compuesta por los dos hemisferios (con sus cuatro lóbulos cada uno) y la corteza cerebral. Baste añadir que los cien mil millones de neuronas del cerebro humano (con una media de más de mil conexiones cada una) y el concurso de unos 50 tipos de neurotransmisores ofrecen un potencial asombroso para el procesamiento de experiencias e información (a su vez coordinada, codificada, almacenada, modificada), así como todo lo desencadenado en términos de control orgánico, aprendizaje, establecimiento de múltiples relaciones internas y externas, etc ${ }^{16}$. Como es obvio, hay que suponer ahí un gran complejo de circuitos que comprende todas esas esferas y las somete a continua retroalimentación, de modo que cada individuo tiene un particular mapa neuronal en función de sus vivencias de toda índole, a la vez que constantemente remodelado.

Por lo que se refiere a las emociones en particular, parece que el hipotálamo (situado en el centro del cerebro) es el encargado de la respuesta emocional inconsciente y que otras partes del sistema límbico como la corteza prefrontal, cingulada y parahipocámpica intervienen en su aspecto consciente. A medio camino de ambos planos se halla la amígdala, conectada al hipotálamo y la corteza (además de al bulbo), donde convergen las informaciones sensoriales, viscerales y corticales estrechamente relacionadas con las emociones: por un lado, recibe estímulos que desencadenan procesos inconscientes (motores y vegetativos), guardados en una memoria de carácter adaptativo, p.ej. la huida o la lucha ante emergencias y amenazas; $y$, por otro, proyecta hacia el neocórtex la percepción consciente de ese miedo y la posibilidad de aprender de la experiencia, amén de usar la memoria y la imaginación emocionales para desencadenar procesos igual de vívidos, aunque no haya estímulo externo ${ }^{17}$. De este modo, los dos registros se complementan y el resultado es una conducta emocional canalizada por la amígdala, donde se dan cita lo innato y lo adquirido, lo reflejo y lo discriminativo, orientado todo ello -en principiohacia la búsqueda de elementos y entornos de recompensa (alimenticia, sexual, etc.) como palanca de supervivencia y perduración. Las patologías de la amígdala muestran -por contraste- la conexión de ida y vuelta entre los dos niveles: p. ej. cuando hay disociación entre las emociones y las cogniciones de las mismas (lo que se siente y lo que se cree sentir) se impide cualquier coherencia conductual. Aquí también hay una configuración única de la personalidad.

Además de los aspectos motivacionales (deseos, necesidades, propósitos) que generan pulsiones, hay una apertura obvia a los sentimientos que aglutinan y decantan todos esos elementos, hasta constituir algo así como las vías habituales de

${ }^{16}$ Cf. Mosterín, J.: La naturaleza humana, Madrid, Espasa Calpe, 2006, pp.190-ss.

17 Hasta cierto punto, cumple en este ámbito un papel semejante al que Descartes atribuía a la glándula pineal para conectar cuerpo y alma. 
expresión de los estados y reacciones del sujeto. No debe olvidarse el papel modulador de los neurotransmisores, pues afectan al sistema nervioso central y autónomo en varios aspectos, en particular respecto a las emociones y el estado de ánimo: cabe destacar el papel de los neurotransmisores llamados catecolaminérgicos y serotoninérgicos ${ }^{18}$, vinculados tanto a reacciones emocionales inconscientes como conscientes, algunos de cuyos mejores ejemplos son la adrenalina ligada al temor o la dopamina ligada a la recompensa placentera. Las emociones obedecen en los mamíferos a patrones evolutivos automáticos y al aprendizaje individual, consolidados ambos mediante el papel de estas moléculas neuroquímicas que permiten establecer asociaciones y circuitos, lo que a su vez incide en la doble dimensión de la memoria, una implícita o pretética y otra declarativa o explícita, propia del uso consciente de la información ${ }^{19}$. Luego no cabe hablar de sentimientos humanos sin considerar esta infraestructura compleja, donde se imbrican necesidades y estímulos, elementos químicos, reacciones reflejas y elaboradas, actos y conocimientos... en un bucle recursivo sobre el que se asienta el temperamento y a más largo plazo el carácter. Digamos como botón de muestra que un déficit en la circulación de serotonina ${ }^{20}$ supondría un factor importante a la hora de configurar una personalidad propensa al desánimo y al decaimiento, sin incurrir por esto en una explicación unilateral. Igualmente, hay estudios que apuntan diferencias de grado entre hombres y mujeres a la hora de expresar diversas habilidades emocionales, verbales, de memoria, etc., a tenor de sutiles rasgos fisiológicos y bioquímicos de esta índole, los cuales estarían en correlación con los procesos evolutivos y el reparto sexual de las tareas durante muchos milenios ${ }^{21}$.

3.2. Para valorar estos datos básicos debe primar la cautela, claro está, pero no por eso hay que eludir la cuestión y negar el peso de algunos condicionantes que van desde los genes hasta los neurotransmisores. Recordemos en primer lugar que la emoción y la cognición están trabadas desde el origen en la experiencia humana, al igual que lo consciente y lo que no lo es: dada una situación difícil, pongamos por caso, se suda, se siente, se hacen gestos involuntarios, se tiembla, se analiza todo ello, etc., casi a la par. Del mismo modo, se puede hablar de emociones primarias (ira, miedo, alegría, tristeza...) y secundarias (envidia, culpa, vergüenza,

\footnotetext{
18 Además están las neuronas aminoacidérgicas y las colinérgicas, menos activas quizá en este aspecto. En cambio, el protagonismo bioquímico de las 20 clases de endorfinas respecto al bienestar general de la persona es cada más reconocido, así como el papel doble de las neurohormonas, p.ej. la vasopresina o la oxitocina (esta última parece influir como neurotransmisor en el enamoramiento y como hormona en las contracciones del parto).

19 Cf. Belmonte, C.: "El desafío del cerebro", en García Barreno, P. (dir.): La ciencia en tus manos, Madrid, Espasa Calpe, 2000, pp. 444-ss., 426-ss. y 447-450, por orden de exposición.

20 En 1996 se descubrió la importancia de un gen que facilita dicho transporte.

21 Cf. Mosterín, op. cit., pp. 274-277.
} 
calma...) según el peso respectivo de lo reflejo o lo mental más elaborado en cada categoría, pero a condición de no postergar los mecanismos neurales que subyacen a todas ellas ${ }^{22}$, implementados en la larga marcha hominizadora. De hecho, como ha expuesto J. Le Doux, los procesamientos de emociones e ideas difieren en parte y a la vez tienen en común una base orgánica inconsciente, hasta el punto de que cualquier lesión lo trastoca todo, sin olvidar que los resortes emotivos son más antiguos evolutivamente que los intelectuales y por tanto de activación inmediata, como primera reacción que frecuentemente arrastra a lo demás 23 . Los estados emocionales se disparan por sí solos y están en gran medida automatizados, de manera que sólo después pueden asimilarse o controlarse, lo cual no quiere decir que siempre sean atinados y guarden proporción con la experiencia vivida. Visto desde otro ángulo, sería bueno no confundir precedencia con prioridad absoluta, pues no menos importante es la capacidad de retroactuar sobre las condiciones iniciales y modificarlas.

De lo que no cabe duda es de la importancia tremenda de las emociones en el crecimiento, la socialización y la moralidad, por razones evidentes: a través de ellas adquirimos una primera inserción en el mundo, aprendemos antes por el ejemplo afectivo que por la palabra, imitamos y absorbemos valores de todo tipo, conectamos así con los demás de la manera esencial que nos constituye...Baste decir que hay evidencia de la atrofia del cerebro en los niños privados de afecto, así como de las consecuencias de los traumas tempranos sobre la organización neuronal. De ahí la atención que merecen las diferentes etapas de la maduración emocional (lo que envuelve a todo lo dicho por Piaget sobre la inteligencia, por cierto) y que no pueden perderse, so pena de que esas "ventanas" se cierren para siempre y sean irrecuperables. La conclusión es que el filtro emotivo está presente en toda actividad sensorial y mental, y que la realidad se nos hace inteligible por esa vía antes que por ninguna otra24. Cualquier concepto o símbolo se mezcla con los afectos en un ciclo sin fin, hasta el punto de que para algunos estudiosos las emociones son los cimientos de la personalidad en sus variados registros, pero no tanto en clave psicoanalítica como respecto a la génesis y estructuración de la identidad (estarían en la base de todo pensamiento creador) y se añade que cumplen una función arquitectónica, organizadora y orquestal25. Así que no es fácil exagerar su importancia, lo que poco tiene que ver con una suerte de comodín omniexplicativo y menos aún con el sentimentalismo pueril tan en boga hoy.

\footnotetext{
22 Cf. Belmonte, C.: "Emociones y cerebro", Rev.R.Acad.Exact.Fís.Nat. (Esp), Vol. 101, № 1, 2007, pp. 59-68.

23 Cf. Le Doux, J: The Emotional Brain, New York, Simon and Schuster, 1996.

24 Mora, F. (ed.): El cerebro sintiente, Barcelona, Ariel, 2000, p. 19.

25 Greenspan, S. I. y Lieff Benderly, B.: El crecimiento de la mente y los ambiguos orígenes de la inteligencia, Barcelona, Paidós, 1997, p.7.
} 
En cuanto a la moralidad, es revelador el ejemplo a contrario de los psicópatas, de quienes se sabe -por las modernas técnicas tomográficas, etc.- que no activan las partes de su cerebro emocional cuando se les presentan hechos repulsivos desde ese punto de vista, y en cambio sí los procesan lingüísticamente ${ }^{26}$. Podría decirse que hay una frialdad y una asepsia intelectual que eliminan cualquier atisbo de empatía, y lo cierto es que no se ha encontrado ninguna terapia efectiva para ellos, como si la fatal disociación fuera irreversible. Pérdida aún más tremenda si se piensa en las recientes investigaciones sobre las "neuronas espejo" y en que la etología ya adjudica capacidad empática a los mamíferos superiores, entendida como la posibilidad no verbal de atribuir estados mentales a otros seres. Lo cierto es que parece imponerse en bastantes científicos la impresión de que el cerebro primitivo y su conglomerado de pasiones "domina completamente" al más reciente neocórtex, el único que puede "negociar con la realidad"27. Es curioso que las pertinentes críticas dirigidas contra una noción de voluntad libre sin límites a menudo conduzcan al extremo contrario, más allá de que hay exigencias biológicas insoslayables del ser vivo, y acaba por negarse la existencia de un "yo" unitario y relativamente consciente, de una subjetividad articulada y capaz de gobernar con más o menos éxito su propia vida 28 . Sin entrar en la polémica entre monistas y dualistas respecto al insondable problema mente-cerebro, conviene mantenerse lejos de aquel efecto pendular y de sus consecuencias en otros campos, evitando por ejemplo la postura que gira en torno al feroz instinto egoísta que niega la moralidad y la que -por el contrario- la convierte en un tipo de instinto tan arraigado en la naturaleza como cualquier otro ${ }^{29}$. Recuérdese la ambigüedad ideológica del término instinto aplicado al hombre, el hecho de que con esa palabra sólo se nombra algo filogenéticamente adquirido pero en relación a otros muchos factores, y que es peligroso entrar en una definición esencialista de lo humano, especialmente porque éste se caracteriza por la gran disminución de los instintos.

3.3. Volvamos al terreno fisiológico - con estas precauciones de interpretaciónpara afirmar que el cerebro está orientado a la supervivencia antes que a ninguna

\footnotetext{
26 Entrevista a Robert Hare: "Las bases biológicas del psicópata", en Punset, E.: Cara a cara con la vida, la mente y el universo. Conversaciones con los grandes científicos de nuestro tiempo, Barcelona, Destino Booket, 2006, p. 161.

27 Entrevista a Rodolfo Llinás: "El cerebro está encerrado a oscuras", en Punset, op. cit., p.183.

28 Cf. un buen compendio en Rubia, F. J.: El cerebro nos engaña, Madrid, Temas de hoy, 2000; y El fantasma de la libertad, Barcelona, Crítica, 2009.

29 Es conocida al respecto la obra de Hauser, M: The Moral Minds: The Unconscious voice of right and wrong, New York, Harper Collins, 2006; y la producción etológica de F. de Waal, que culmina en la reciente The Age of Empathy: Nature's Lessons for a kinder Society, New York, Harmony Books, 2009. También es interesante al respecto la discusión de Steven Pinker en el extenso artículo "The Moral Instinct", New York Times, 13-1-2008.
} 
otra cosa y que las emociones hacen una aportación reguladora, en parte innata y en parte modificada por la cultura. En el escenario donde se generan éstas concurren el medio interno, el sistema visceral, vestibular y musculoesquelético, así como los circuitos neurales que permiten unificar las sensaciones de cada caso ${ }^{30}$. Además, debe pensarse en el organismo como un conjunto unitario de procesos, aunque no sabemos bien cómo se engarzan y dan lugar a la comprensión siquiera relativa de las experiencias y del mundo, es decir, no hay explicaciones concluyentes sobre el continuo de cuerpo-cerebro-mente-realidad. Eso no impide ver a la emoción como uno de los hilos conductores que engranan los planos y que permite introducir una nueva secuencia que va del estado interno circunstanciado hasta el sentimiento, entendido como "idea" fundada en "patrones neurales que cartografían el estado corporal", lo que permite obtener una "imagen mental" del mismo31. Si el sentimiento es un "mapa" de segundo grado que ya implica un componente de ideación y una distancia objetivadora, quizá habría que añadir que la emoción consiste en la previa toma de datos que fija las coordenadas de la experiencia en el momento, de modo análogo a como el pensamiento sería la interpretación cartográfica posterior para guiarse en un territorio conformado por el ensamblaje de cuerpo y mundo. Por otro lado, en el paso desde la sensación a la percepción y a la autoconciencia parece haber una transición fluida, pero sin descartar el salto hacia algo cualitativamente nuevo, esto es, una emergencia en la autoorganización del sistema que no sabemos descifrar.

Es cierto que hay afectos primordiales, pero -indica Damasio- eso no permite suponer que el complejo de emociones y sentimientos sustituya al razonamiento, sino que sólo lo ayuda y acelera, cual "corazonada" primero, e imprescindible anticipación de los efectos de los actos después; de modo que la alianza de intelecto y afectos encaja dentro del empeño global de "biorregulación" y búsqueda de una homeostasis individual y colectiva, lo que incluye a la "cooperación" como eficaz herramienta adaptativa, base a su vez de la ética y la política ${ }^{32}$. Decide el carácter estratégico y utilitario del asunto: las emociones son necesarias, por un lado, para lograr los propósitos individuales (a través de la información que proporcionan) y, por otro, para servir de cemento socializador (reconocimiento y coordinación de conductas) en aras del bien común, luego así se explica la selección evolutiva del altruismo. El complejo emotivo-sentimental permite abrirse a los demás y crear

\footnotetext{
30 Damasio, A.: La sensación de lo que ocurre: cuerpo y emoción en la construcción de la conciencia, Madrid, Debate, 2001, p. 61.

31 Damasio, A.: En busca de Spinoza. Neurobiología de la emoción y los sentimientos, Barcelona, Crítica, 2005, p.88.

32 Damasio: En busca de Spinoza, pp. 141, 144, 157-ss. y 168-ss. La alegría y la tristeza como sentimientos eje tienen distinta relación con la corteza prefrontal: la primera activa ésta con efectos benéficos y la segunda al revés, lo que está en consonancia con las intuiciones básicas de la ética espinoziana, cf. pp. 100-ss. y capítulos 6 y 7.
} 
sinergias muy útiles para todos, tanto en aspectos mentales internos como pragmáticos externos, lo que en definitiva ayuda a la mejor evaluación de las experiencias y a la solidaridad, es decir, a la disposición ético-política. Su lazo con las motivaciones más profundas de la persona (metas, valores...) y con las relaciones intersubjetivas (identificación en el grupo, imitación, etc.) convierte a este tema en uno de los protagonistas de la existencia ${ }^{33}$.

El problema surge cuando, a la luz de estos hallazgos, se trata de focalizar toda la atención en la manipulación científica de los afectos (de la política se hablará luego), lo que conduce a buscar "la fórmula química de la felicidad" con evidente simpleza que olvida, entre otras cosas, que las vías neurales del dolor están muy próximas a las de las emociones positivas ${ }^{34}$. El error está en fragmentar la personalidad para hipertrofiar alguna faceta y convertirla en objeto de mera intervención instrumental. Por el contrario, emociones, sentimientos e ideas se mezclan en el día a día del sujeto, tanto si coinciden entre ellos como si no: el flujo orgánico, el de la mente y el de la conducta convergen en el mismo río, la dificultad analítica proviene de que no es fácil calibrar su densidad ni diferenciar esas aguas procelosas, como tampoco saber dónde y cuándo el afecto inyecta energía a la razón o ésta lo ilustra y reconduce sin más. En cualquier caso, he aquí el contacto con la tradición filosófica naturalista aludida más arriba, al identificar ese magma psicofísico como el substrato del individuo (incluida su importante dimensión preconsciente), sin caer en el vacuo optimismo de la voluntad que supuestamente todo lo puede, y que ahora sería de corte biotecnológico. Lo que cabe llamar la sabiduría del cuerpo coexiste con el riesgo de la pasión ciega, del error y de la manipulación. Es verdad que en Heráclito y Spinoza prima el afán de racionalidad, mientras que Schopenhauer y Nietzsche lo relegan a un segundo plano (consecuencia de la deriva desengañada de la Modernidad), pero todos comparten la convicción de que hay fuerzas profundas en el organismo que marcan la pauta de la vida. Después, las emociones, los hábitos y la lucidez que pugna por reorientar la experiencia tejen el nexo que va del carácter al destino, esto es, de la naturaleza dada a lo esculpido en ella.

\section{Una aplicación ética y antropológica}

4.1. Este breve recorrido por algunos parajes de la filosofía y de la ciencia enseña cosas de interés, por ejemplo que de entrada no somos dueños de nuestras emociones y sentimientos, aunque podamos revisarlos después e incluso educar esas

33 Cf. un buen resumen en Choza, J. (ed.): Sentimientos y comportamiento, Murcia, Universidad Católica, 2003.

34 Cf. Cyrulnik, B.: De cuerpo y alma. Neuronas y afectos: la conquista del bienestar, Barcelona, Gedisa, 2007, cap.2. 
disposiciones. Pero hay algo en el fondo de cada uno que no parece cambiar, es decir, el carácter encierra una sensibilidad y unas propensiones que implican una forma sutil de lo que llamamos destino, como rubrica la literatura o la sabiduría popular. La novedad es que hay articulaciones teóricas que eluden por igual el fatalismo y el mero voluntarismo, lo que permite un conocimiento más amplio de los aspectos en liza y de sus consecuencias prácticas. Así se evitará el viejo error -ya denunciado por Walter Benjamin- de asociarlos a la culpa y la desgracia, cuando en realidad el carácter pertenece a la esfera de la naturaleza y es algo en principio amoral, y el destino se juega en el terreno de quien aspira a un margen de libertad para ser feliz ${ }^{35}$. Como ya se dijo al inicio, el objetivo es integrar pasión y acción, naturaleza e historia, emoción e inteligencia, sin dar nada por decidido de antemano ni pretender una resolución de los conflictos. De hecho, puede pensarse que los polos de estas parejas guardan una proporción inversa, según sostienen muchos, pero lo interesante es apreciar sus vínculos profundos, lo que para nuestro tema supone que las emociones tienen una proyección "protoconceptual" y sirven para detectar asuntos relevantes, propiciar las reacciones fisiológicas de la acción y motivar el logro de objetivos vitales a largo plazo; todo ello en el marco de una concepción sistémica e interaccionista de la mente, donde el sistema emocional colabora (y a veces se solapa) con el conceptual, el sensorio-motor o el perceptual en un camino de ida y vuelta, de modo que la educación sentimental consistiría en una racionalidad/moralidad que intente coordinar esas diversas capacidades y aportaciones ${ }^{36}$. No deberíamos conformarnos con menos.

En otro orden de cosas, no sólo hay que mentar el temperamento básico, así como los aprendizajes individuales que van conformando el carácter, sino tener muy en cuenta las poderosas influencias sociales que inciden sobre las emociones $\mathrm{y}$, en general, las muchas contingencias que ponen a prueba aquel edificio de la subjetividad. El conjunto relativamente estable de la persona se comprende mejor en relación al eco-sistema físico y simbólico del que forma parte, y eso incluye verse sacudido por sucesos imprevistos que le imprimen cambios, a veces traumáticos. Respecto a lo primero, es obvio el importantísimo proceso de socialización que moldea la existencia desde el nacimiento, pero debe añadirse que esa mediación del entorno incluye de modo preferente la adquisición de roles que a su vez responden a un marco institucional dado, de manera que -según Wright Mills- el carácter estaría constituido por los rasgos orgánicos (fisiología e impulsos), la estructura psíquica (percepciones y emociones) y la persona entendida como un "actor" motivado y competente en función de los diversos roles sociales que asume ${ }^{37}$. Es imposible

35 Cf. Benjamin, W.: Schicksal und Charakter, en Zur Kritik der Gewalt und andere Aufsätze, Frankfurt, Suhrkamp, 1971, pp. 70, 74 y 76.

36 Cf. Broncano, F.: "La educación sentimental. O de la difícil cohabitación de razones y emociones", Isegoría, 25, 2001, pp. 41-61, en particular pp. 49-ss.

37 Cf. Wright Mills, Ch. y Gerth, H.: Carácter y estructura social, Barcelona, Paidós, 1984. 
entender al sujeto -en lo que es y hace- sin considerar este factor que va calando y lo tiñe todo, hasta el punto de que hombre y máscara llegan a confundirse en el gran teatro de la vida social. Por eso hablamos de ciertas disposiciones de segundo grado que se mezclan con las innatas y arrojan el precipitado de la autoexpresión en el mundo, de manera que la hexis y la habitudo encuentran aquí cumplido desarrollo y objetivación pública (a su vez en estrecho contacto con el sentido habitual de $m o s$ ), dentro de una constante retroacción.

En una línea similar habla P. Bordieu de la "historia incorporada", es decir, encarnada en los cuerpos mediante un sistema de disposiciones que llama habitus ${ }^{38}$ : son reglas, costumbres, prejuicios, esquemas de pensamiento y acción... que se han objetivado y rutinizado hasta el punto de ser ya inconscientes. Si el trabajo intelectual se ocupa de hacer explícitos los presupuestos del llamado sentido común, así como de cuestionar el papel regulador de esta suerte de imaginario colectivo, no es menos cierto que las personas están impregnadas de todo ello desde el principio de su existencia y es imposible hablar de carácter y destino sin tenerlo en cuenta. Además de fijarse en el subsuelo biológico para ver un fuerte condicionamiento, hay que incluir enseguida este otro de índole socio-histórica, pues ambos se unen hasta conformar un sedimento de alcance incalculable. El ejercicio de la autonomía personal encuentra ahí, paradójicamente, su condición de posibilidad (adquisición de una cosmovisión y de habilidades prácticas) a la par que un serio obstáculo (horizonte y margen de maniobra limitados, e incluso eventual coerción). Semejante vínculo entre dependencia e independencia debe considerarse, por lo demás, una constante de cualquier acercamiento que no sea sólo abstracto al tema de la identidad y la libertad.

Lo peculiar de nuestro tiempo de crisis global es que tampoco en ese terreno hay estructuras demasiado estables, al menos en las llamadas sociedades ricas. Fenómenos como la globalización y la aceleración de los procesos históricos (sobre todo por razones tecnológicas), el desbordamiento de muchos códigos simbólicos y la hibridación cultural, el pluralismo no exento de anomia, etc., impiden durar a esos modelos sociales como antaño. En realidad, bien puede hablarse del incremento de las contingencias históricas (campo justamente opuesto a la noción tradicional de destino), donde una compleja interacción de variables, el azar, el accidente, la desviación, etc., dan lugar a giros bruscos y rumbos inesperados ${ }^{39}$. Y esto no sólo se aplica al ámbito colectivo, sino también al íntimo en la medida en que esa atmósfera llena de estímulos, prisas, oportunidades, riesgos e inseguridades deja poso en la formación de los caracteres y propicia la aparición de un nuevo estilo de vida o destino epocal, presidido por la incertidumbre y la sobreabundancia de emociones

\footnotetext{
38 Bordieu, P.: Lección sobre la lección, Barcelona, Anagrama, 2002, p. 41.

39 Véase una buena lectura del tema desde distintas ópticas en Roldán, C. y Moro, O. (eds.): Aproximaciones a la contingencia, Madrid, Libros de la Catarata, 2009.
} 
contradictorias, toda vez que la historia impone su ritmo e incluye nuevas formas de socialización. Por otro lado, hay evidencias empíricas que muestran la fragilidad moral del carácter ante las diferentes situaciones, con el resultado de que la presión del ambiente suele tener más peso a la hora de optar por un determinado comportamiento que los rasgos de una personalidad acrisolada, según indican múltiples experimentos ${ }^{40}$. En resumen, las inercias orgánicas y psico-sociales en el sujeto no impiden que éste se muestre lábil e inconsistente, sometido a muchas contingencias y a un cierto situacionismo que a menudo le arrastran. Luego la identidad aparece de nuevo como algo sumamente complejo y a menudo oscilante, problemático.

4.2. Son diversos los factores implicados, pero lo que sorprende es que bastantes especialistas afirmen que la parte consciente de la vida cerebral es pequeña y se aventura que los trabajos de laboratorio indican que "las decisiones supuestamente libres se toman en un $80 \%$ basándose en informaciones subconscientes", todo ello dentro de la muy deformada visión del mundo que construyen los humanos ${ }^{41}$. No es anecdótico que esto o diga el actual presidente de la Organización Internacional para la Investigación del Cerebro, quien insiste en que la experiencia vital con frecuencia se ve dirigida por emociones incontrolables, en el marco de una clara limitación perceptiva e intelectual. Cuesta aceptar -por unilateral y simplificador- que la conciencia sea la punta de un iceberg, lo que deja malparada a la autodeterminación, pero tampoco se puede negar esa trama subterránea, lo que incluye la pasividad reactiva o la compulsión que en tantas ocasiones parecen dirigir los actos. Sea como fuere, las presiones internas y externas conducen hoy más que nunca al aumento de las "enfermedades de los afectos" (por ejemplo las depresiones o la enfermedad bipolar), con su obvia "afectación de los circuitos cerebrales de la emoción" 42 . Lo grave es que haya casi una epidemia (10-15\% de la población y creciendo) de disfunciones y sufrimientos de esta índole, cosa que importa mucho al mostrar un estado de la cuestión que reúna facetas orgánicas, psíquicas y sociales, por lo que no es difícil concluir que algo marcha francamente mal en la gestión colectiva de las emociones...

Dado este panorama y a la vista del poliperspectivismo constitutivo en la relación sujeto-mundo, sugiero una aproximación a la naturaleza humana que gire en torno a la perplejidad y al derecho a dudar, postura alejada por igual del supuesto

40 Cf. Viciana, H.: “¿Hacer de la necesidad virtud? Apuntes sobre las transformaciones de la Ética por el influjo de las ciencias empíricas", en Diosdado, C., Rodríguez Valls, F. y Arana, J. (eds.): Neurofilosofía. Perspectivas contemporáneas, Madrid, Thémata \& Plaza y Valdés, 2010, pp. 11-35. El autor recomienda en particular la obra de Appiah, A.: Experiments in Ethics, Harvard University Press, 2008.

41 Entrevista a Carlos Belmonte, El País semanal, 13-09-2009, p. 31. Se incluirían aquí los famosos hallazgos de B. Lisbet a propósito de las reacciones preconscientes, entre otros.

42 Cf. Belmonte, C.: "Emociones y cerebro", loc. cit., p. 68. 
imperio de la razón o del inconsciente automatismo neurológico, pues ambos aniquilan ese rasgo humilde pero decisivo de nuestra condición (el animal no duda nunca de manera genuina). No basta con apelar a ciertos mecanismos lógicos $\mathrm{u}$ orgánicos para despachar las actividades intelectuales y morales, dado que aquellos son condiciones necesarias pero no suficientes de la vida psíquica plena. En cambio, la duda humaniza porque genera un momento de pausa contrario al hábito o la inercia, y eventualmente da paso a la tolerancia, a la reflexión crítica y a la elección madura, lo que también incluye elucidar y sopesar las emociones en liza. Lejos de ensalzar la duda paralizante o la que mata la respuesta espontánea, se trata de reconocer los muchos interrogantes y tribulaciones identitarias que asaetean a quienes no son tan sabios como quisieran ${ }^{43}$. Es necesario, entonces, debatir desde parámetros de complejidad que desborden las viejas dicotomías de libertad y determinismo, consciencia e inconsciencia, biología y lucidez..., tanto por la exclusión mutua que suponen como por su mezcla de lenguajes distintos. Lo normal, por el contrario, es que en la persona haya interacciones entre los sistemas conceptuales, perceptivos, emocionales, sensorio-motrices, culturales, sociales, etc., con los correspondientes tipos/grados de heteronomía y de autonomía según los casos y circunstancias. Es decir, hay diferentes tipos y grados de respuestas en las reacciones somáticas reflejas, en la conciencia, la atención y los impulsos, acordes con niveles variables de opacidad y esclarecimiento de la conducta, con el peso del estímulo o del contexto y con la posibilidad más o menos abierta de actuar... Luego hay elementos más que suficientes para dudar, se trate de la conducta privada que resulte de ahí o -en otro plano- de cualquier teoría sobre estas cuestiones.

Se impone así la equivocidad del tema y además la perenne incertidumbre en el debate de la cuestión mente-cerebro. Nadie puede negar la evidencia científica de los automatismos cerebrales, pero tampoco la experiencia de la intencionalidad subjetiva, y si es cierto -desde otra perspectiva- que las emociones influyen en los razonamientos, no es menos claro que pensar también puede modificar el ánimo. La dirección es doble, biunívoca, como muestra la importancia de los traumas o de las patologías cerebrales en general, a la vez que la autosugestión cognitiva o las psicoterapias, pongamos por caso. Hoy no parecen de recibo ni el dualismo ontológico ni el monismo fisicista de corte mecánico, y es que no tenemos respuestas satisfactorias a las preguntas sobre el fundamento orgánico de la inteligencia o de la libertad, de tal manera que el llamado emergentismo es una forma de nombrar en clave ascendente algo a la postre ininteligible, como el reduccionismo lo hace en

\footnotetext{
43 Es interesante apuntar que en Oriente (India, China, Japón...) la sabiduría consiste en des-identificarse, en rebasar la noción del "ego" y sus ataduras, lo que permite una conducta espontánea y casi sin deliberación, ajena a cualquier idea de carácter y destino. Este abandono de una subjetividad ilusoria y de un proyecto definido (moral, finalista, instrumental...) de la acción parece que desdramatiza y relativiza todas estas cuestiones.
} 
clave descendente. Es dudoso incluso que alguna vez haya una satisfactoria explicación de esos asuntos, pero en el ámbito particular que nos ocupa parece obvia la relación multilateral y retroactiva entre temperamento, emoción, sentimiento, comportamiento, intelecto, situación... Para concretar un poco, puede verse al carácter como la instancia mediadora y tal vez integradora en parte de esos elementos desde el punto de vista de la experiencia subjetiva y de la praxis pública. Insistamos en que los rasgos neurobiológicos, hipotalámicos, hormonales, etc. confieren una tonalidad sensitiva y emocional al sujeto de por vida y que éste es su particular destino, no siempre agradable, pero tampoco visto como fatal desenlace sino como innegable punto de partida, donde el carácter consiste en la difícil síntesis de lo dado y lo adquirido mediante las muchas formas de interacción y aprendizaje.

Entra así en juego cada peripecia biográfica, original e intransferible, condicionada por los rasgos psicofísicos particulares y los niveles de la identidad (somática, temperamental, educativa, dotada de proyectos de vida, etc.), lo que habla ya de un evidente pluralismo dentro de cada individuo, a su vez actualizado y modelado a lo largo del tiempo dentro de aquellos límites. Casi podría decirse que la única configuración duradera de la subjetividad es la de los humores, por decirlo al modo antiguo, como único baluarte seguro frente a la disolución del yo (recuérdese, por ejemplo, que para Hume sólo habría un "haz o colección de percepciones diferentes...en perpetuo flujo", Treatise I, IV, 6). Aun cuando no haya un sujeto substancial y la memoria o los hábitos no basten para constituirlo, queda una forma de sentir que lo impregna todo, debajo de la dispersión en el contenido de la conciencia. $\mathrm{Si}$, como es sabido, la palabra educación proviene del latino educere que es "sacar a la luz" lo que hay en uno, sería bueno tener en cuenta esa manera de ser previa y básica: algo así como la brújula inconsciente de la navegación y un mapa de las reacciones elementales, afinidades y rechazos, etc., aunque no haya unos rumbos fijos. Desde luego que la aventura personal -fundada en esa infraestructura de propensiones emocionales- queda sólo condicionada y únicamente podrá ser entendida mediante la narración a posteriori, pero reconocer esa pluralidad intra e intersubjetiva también demanda una lectura moral.

4.3. Nos parece aconsejable una ética ligada a la libre combinación individual de los muchos factores en juego, adaptada a la idiosincrasia de cada uno, y que bien podría llamarse a la carta, lo que no significa en absoluto que sea caprichosa o arbitraria. Por el contrario, hay que advertir desde el comienzo contra el modelo social vigente que encomia la frivolidad y el consumo irresponsable como estilo de vida (¿también en el terreno de los valores?), lo que guarda relación con el uso de técnicas publicitarias en sentido mercantil y político para manipular las emociones, una vez que éstas han sido puerilmente entronizadas al margen de la reflexión crítica. Prácticas como el llamado storytelling o el neuromarketing son dos buenos ejem- 
plos de tales propósitos, sea en el puro nivel retórico de contar historias subyugantes o en la resolución supuestamente científica de cómo se eligen marcas comerciales, caminos ambos mucho más eficaces y sibilinos para dirigir al sujeto que la vieja autoridad impositiva o el típico bombardeo de mensajes. Y es que en este mundo de aparentes gratificaciones sin límite lo que a menudo resulta escamoteada es la verdadera libertad de pensamiento y elección, algo que suprime la capacidad de dudar y componer una decisión propia o una acción colectiva en el marco de una auténtica democracia. Las emociones son un campo de juego tan arraigado y poderoso como delicado y vulnerable, luego necesitan ir siempre de la mano con la razón y con las instituciones, pues sólo las tres instancias unidas pueden contribuir a la limpieza y cooperación de los procesos éticos y políticos.

Lo que proponemos, frente a la tradición universalista, es una ética razonable de bricolaje personal (que tiene en cuenta esas tres dimensiones), surgida de la conciencia plena de la complejidad neurobiológica del individuo, de su irreductible temperamento, de lo contradictorio de los ingredientes del carácter, del peso de las situaciones y las contingencias... En sentido objetivo, es la respuesta ante la incertidumbre que late, por un lado, en la comprensible parcialidad y limitada aplicación de los grandes modelos éticos a los diferentes campos de la acción moral, pues todos dejan algo fuera y chocan entre sí; y, por otro, en la existencia de imperativos a veces irreconciliables (Morin habla de los deberes egocéntricos, genocéntricos, sociocéntricos y antropocéntricos, que finalmente deberían extenderse a la TierraPatria $\left.{ }^{44}\right)$. Es decir, no tenemos un patrón de medida universal, aparte de unas pocas generalidades ${ }^{45}$, mucho menos la panacea para las dudas y ni siquiera un vademécum, como tampoco existe una armonía preestablecida de valores, obligaciones e intereses, luego hay que optar continuamente y hacerlo sin red de seguridad, creando una especie de moral de geometría variable en continua recomposición. Tal vez en eso consista el llamado arte de vivir, donde hay pocas certezas, una realidad inconmensurable y constantes desafíos que cada uno lidia como mejor puede, desde sus rasgos psicofísicos únicos. Y ahí cumplen un importante papel la sensibilidad y las tendencias que se llevan dentro, nunca idénticas a las de otro, máxime cuando se trata de hilar fino en los casos concretos de la vida cotidiana que exigen la más sutil epiqueya o adaptación de la norma universal a lo particular.

Lo que debe buscarse es una convergencia hacia lo común, en la medida en que "Nuestras intuiciones, emociones y sentimientos morales, en parte anclados en nuestro genoma, son la piedra de toque de las teorías éticas (...) En nuestra refle-

\footnotetext{
${ }^{44}$ Cf. Morin, E.: El método 6. Ética, Madrid, Cátedra, 2006, p. 55. Luego puede haber complementariedad o mera concurrencia, pero también antagonismo, lo que exige una elección o apuesta según la circunstancia y sin certeza alguna sobre las consecuencias de los actos, cf. p. 63.

45 Generalidades importantes del tipo de "trata a los demás como quieres que te traten", etc., pero no capaces de resolver por sí solas conflictos intrincados sobre el terreno y día a día.
} 
xión moral se da un proceso continuo en que nuestras emociones guían a nuestras teorías y nuestras teorías educan a nuestras emociones (...) Pero con frecuencia nuestros sentimientos responden a un procesamiento de la información más minucioso y profundo y no por inconsciente menos sofisticado que las ideologías y teorías conscientemente articuladas. Muchos de los mayores crímenes de nuestro tiempo se han debido a la desactivación de nuestros sentimientos de compasión y empatía y a la aplicación implacable de ideologías aprendidas en los libros. En cualquier caso, el ser una buena persona tiene más que ver con los sentimientos, las emociones y las actitudes y disposiciones que con el conocimiento de (o acuerdo con) alguna abstrusa teoría ética" 46 . Parece, pues, que hay que confiar en lo que no podemos controlar por completo, tanto porque tiene un pragmático origen evolutivo como por la subconsciencia inevitable de ciertos procesos orgánicos, claro que sin abandonar la posterior vigilancia racional. Digamos que en las decisiones morales existe al menos un primer elemento de contraste en el sentimiento, sin caer por ello en el buenismo tan aviesamente atacado, dicho sea de paso, por los halcones de toda condición que se burlan de la supuesta debilidad de las palomas. Acaso se trate de reivindicar la brújula intuitiva mencionada más arriba como primera guía para la navegación moral, aunque luego deba traducirse en diferentes rutas y códigos (también jurídicos y políticos), que a su vez tengan en cuenta los vientos y las corrientes de cada situación.

Ante la insistencia de muchos neurobiólogos en la prioridad de las decisiones preconscientes (fruto de factores casi desconocidos) y en que luego sobreviene la deliberación (es decir, la conveniente racionalización de las mismas), tal vez sería bueno desmitificar la idea de libertad y no atribuirla sólo a la conciencia sino al ecosistema cuerpo-mente-entorno, con sus múltiples registros e interacciones; casi por lo mismo que, ante la evidencia etológica y neural de las raíces evolutivas (tanto animales como emocionales) de la moralidad, dada la eficacia adaptativa del altruismo y de la empatía, sería oportuno considerar la ética como un resultado biológicocultural permanentemente puesto a punto ${ }^{47}$. Luego es preciso flexibilizar los supuestos antropológicos de la acción humana y relativizar las grandes categorías morales (libertad, bien, valor, razón, fin...) que suelen aplicarse para definirla, es decir, concebirlas desde las varias dimensiones que intervienen (bio-culturales, históricas, ecológicas, etc.), a la vez que atender al peso del carácter a la hora de coordinar todo ello. Parece oportuno, entonces, desembocar en una actitud ética más

\footnotetext{
46 Mosterín, J.: op. cit. pp. 376-ss. El autor insiste en que no defiende un emotivismo moral (equivalente al fenomenismo en la física) y que lo deseable es un equilibrio reflexivo entre teoría y sentimientos, pero dando el realce pertinente a éstos, ya que proporcionan algo análogo a lo que son las observaciones empíricas para la ciencia.

47 Cf. Pániker, S.: Asimetrías, Barcelona, Debate, 2008, pp. 126-ss. y 162-ss., respect. Parece ser, añade, que sólo llega a la conciencia la millonésima parte de toda la información que el organismo humano procesa por segundo.
} 
humilde que la del antropocentrismo más o menos idealista de turno, y, segundo, más integradora de variables e incluso de idiosincrasias individuales. Sólo a partir de ahí estarán mejor fundados los acuerdos y las normas compartidas, los consensos y las leyes, y otro tanto puede decirse de las relaciones interpersonales, sostenidas por un reconocimiento no sólo abstracto de los otros. En una palabra, lo decisivo es bajar del discurso abstracto y biempensante al abrupto terreno de la experiencia intra e intersubjetiva diaria.

El resultado es una mezcla de responsabilidad e irresponsabilidad moral, dados los factores inconscientes, los imprintings formativos, los errores involuntarios, las derivas a veces incontrolables de los actos y las presiones externas; de manera que hay que escapar a la aporía de optar en abstracto entre libertad y determinismo para concentrarse en el empeño ético de compadecer, comprender y religar a todos los seres cuanto sea posible, en los diversos planos de relación ${ }^{48}$. Otra cosa es el ámbito jurídico, pero no debería ser del todo ajeno a esto, como ya indicó Hume. Ser una "buena persona" parece muy vago y, sin embargo, sabemos intuitivamente algo de lo que implica, por ejemplo ese triple afán solidario ejercido con sinceridad. El resto debe trabajarlo cada uno en el marco de esa co-acción (en el doble sentido de lo que es coercitivo y multilateral compartido), cosa que exige mucho más esfuerzo que hacer grandes declaraciones de principios, sin olvidar que bastantes dudas permanecen irresolubles y que el humor siempre es aconsejable para gobernar los propios humores... En definitiva, hay que actuar a todos los efectos como si fuéramos libres, aunque no sepamos hasta qué punto es así, pero no pedir mucho más que "jugar bien las cartas" que a uno le han tocado en suerte por su carácter, convicciones y circunstancias, esto es, hacerlo con inteligencia y sin trampas, lo que no es poca cosa para ser co-autor del propio destino... A la llamada suerte moral se añade la pericia del jugador, quien tiene que saber conjugar las reglas sociales del juego con las de su propio código (genético y de conducta, por así decir), si quiere lograr un poco de felicidad.

Luciano Espinosa Rubio

Facultad de Filosofía

Universidad de Salamanca

espinosa@usal.es

48 Cf. Morin: op. cit., pp. 109 y 220, respect. 